\section{Case Reports in Neurology}

Case Rep Neurol 2021;13:225-232

DOI: $10.1159 / 000515154$

Published online: April 12, 2021
(C) 2021 The Author(s)

Published by S. Karger AG, Basel www.karger.com/crn

This article is licensed under the Creative Commons Attribution-NonCommercial 4.0 International License (CC BY-NC) (http://www.karger.com/Services/OpenAccessLicense). Usage and distribution for commercial purposes requires written permission.

\title{
Stroke due to Left Atrial Appendage Thrombus after Pulmonary Vein Isolation despite Novel Oral Anticoagulant: A Case Report
}

\author{
Woon Hyung Chae ${ }^{a}$ Heinrich Wieneke ${ }^{b}$ Iryna Dykun ${ }^{c}$ \\ Cornelius Deuschl $^{d} \quad$ Martin Köhrmann $^{\text {a }}$ Benedikt Frank ${ }^{\mathrm{a}}$ \\ aDepartment of Neurology, University Hospital Essen, Essen, Germany; ${ }^{b}$ Department of \\ Cardiology and Angiology, Elisabeth Hospital, Essen, Germany; 'Department of Cardiology \\ and Vascular Medicine, West German Heart and Vascular Center Essen, University \\ Hospital Essen, Essen, Germany; ${ }^{d}$ Institute for Diagnostic and Interventional Radiology \\ and Neuroradiology, University Hospital Essen, Essen, Germany
}

\section{Keywords}

Novel oral anticoagulation · Stroke $\cdot$ Catheter ablation · Drug activity $\cdot$ Plasma concentration

\begin{abstract}
In patients with atrial fibrillation, catheter ablation is suggested to reduce the mortality rate and is thus frequently performed. However, peri- and postprocedural thromboembolic complications as well as high recurrence rates of atrial fibrillation limit its advantages and require concomitant anticoagulation. With the advent of novel oral anticoagulants (NOACs), fixed dosing without routine laboratory monitoring became feasible. Nevertheless, several factors are associated with either an overdose or an insufficient drug activity of NOACs. We report on a patient with atrial fibrillation undergoing catheter ablation and cardioversion suffering from ischemic stroke despite being under oral anticoagulation. It turned out that the drug activity of the NOACs used was repeatedly insufficient in spite of regular intake and adequate dosing. In sum, drug activity controls should be taken into consideration in patients with thrombotic events despite oral anticoagulation with NOACs.




\section{Case Reports in Neurology}

Case Rep Neurol 2021;13:225-232

DOI: $10.1159 / 000515154$

(c) 2021 The Author(s). Published by S. Karger AG, Basel www.karger.com/crn

Chae et al.: Stroke after Catheter Ablation despite Novel Oral Anticoagulant

\section{Introduction}

Catheter ablation is shown to reduce recurrence rates of atrial fibrillation compared to treatment with antiarrhythmic drugs only [1-3]. In addition, ablation reduces all-cause mortality among patients with heart failure and atrial fibrillation [4]. However, studies regarding the risk of thromboembolic events after cardiac intervention are controversial. While some studies suggest a reduced risk of stroke [5-7], others show no significant decrease in the risk of cerebrovascular events after cardiac intervention in patients with atrial fibrillation [8-10]. Furthermore, there is a marked incidence of thromboembolic complications associated with ablation procedures and cardioversion [11]. Consequently, pharmacological prevention with oral anticoagulation is of great importance. According to current guidelines, oral anticoagulation for patients with atrial fibrillation is recommended depending on the $\mathrm{CHA}_{2} \mathrm{DS}_{2}$-VASc score [12].

Traditionally, vitamin $\mathrm{K}$ antagonists such as warfarin or phenprocoumon with frequent international normalized ratio (INR) controls were widely used for this purpose. However, the advent of novel oral anticoagulants (NOACs) facilitated a fixed dosing of the drug without the requirement of a routine coagulation test due to the predictable pharmacokinetic profiles of the substances [13]. Further advantages of NOACs are a rapid onset of action and fewer drug-drug interactions than with vitamin $\mathrm{K}$ antagonists [14, 15]. For quantitative measurement of thrombin and factor Xa inhibitors (diluted) thrombin time tests and anti-factor Xa chromogenic assays were established, respectively [13, 16-18].

Nevertheless, there have been several cases in which NOACs were found to be either below the therapeutic range or overdosed, resulting in a higher risk of thromboembolic complications or bleeding [19-21]. Therefore, administering NOACs without questioning their efficacy according to individual properties could lead to detrimental consequences. Below, we report on a patient with stroke after catheter ablation and cardioversion for symptomatic atrial fibrillation with low drug activity of apixaban and dabigatran.

\section{Case Presentation}

A 66-year-old male patient was admitted to the cardiology department for elective pulmonary vein re-isolation for the treatment of symptomatic persistent atrial fibrillation. His body mass index (BMI) was $30.4 \mathrm{~kg} / \mathrm{m}^{2}$ (weight: $93 \mathrm{~kg}$; height: $1.75 \mathrm{~m}$ ) and his creatinine clearance $102.8 \mathrm{~mL} / \mathrm{min}$ (according to the Cockcroft-Gault equation; normal range: 80-120 $\mathrm{mL} / \mathrm{min}$ ). Further diseases were hypertension and asthma. Four years earlier, he had undergone pulmonary vein isolation with following electrical cardioversion, and soon after suffered from recurrence of atrial fibrillation with intermittent palpitations.

Oral anticoagulation with $2 \times 5 \mathrm{mg}$ apixaban was administered for prevention of thromboembolic events. Last intake was the day prior to the intervention. Preprocedural transesophageal echocardiography on the day of ablation excluded an intracardiac thrombus (Fig. 1a). Pulmonary vein isolation by radiofrequency ablation with concomitant electrical cardioversion was performed. In order to prevent thromboembolic procedural complications, heparin was administered intravenously during the intervention. Due to an insufficient activated clotting time (ACT) of $234 \mathrm{~s} 1 \mathrm{~h}$ and $15 \mathrm{~min}$ after initial application of 5,000 IE heparin, another 5,000 IE heparin were administered, achieving an ACT of 278 s 25 min later. In order

\section{Karger'=}




\section{Case Reports in Neurology}

Case Rep Neurol 2021;13:225-232

DOI: $10.1159 / 000515154$

(c) 2021 The Author(s). Published by S. Karger AG, Basel www.karger.com/crn

Chae et al.: Stroke after Catheter Ablation despite Novel Oral Anticoagulant

to achieve an ACT target $>300 \mathrm{~s}$, another 2,500 IE (cumulative dose of all administered heparin: 12,500 IE) were administered. Apixaban was re-initiated on the same day.

After ablation, the patient was free of symptoms and mobile on the ward. On the following day, $30 \mathrm{~h}$ after ablation, he was found with acute-onset left-sided hemiparesis, dysarthria, and neglect (National Institutes of Health Stroke Scale score 8). Emergency cranial computed tomography (CT) imaging showed no early ischemic changes or intracerebral hemorrhage. However, CT angiography revealed an occlusion of the proximal M1 segment of the right middle cerebral artery, and the patient was transferred immediately to our neurology department. Due to prior intake of oral anticoagulation, thrombolysis was contraindicated, and the patient was directly transferred to the Angio Suite. Successful mechanical thrombectomy was performed with one stent-retriever assisted vacuum-locked extraction (SAVE) with nearly complete reperfusion (Thrombolysis in Cerebral Infarction scale grade 2b) without any complications (Fig. 1d) [22].

CT imaging on the following day demonstrated a small infarct in the right basal ganglia. Although transesophageal echocardiography prior to catheter ablation revealed no pathological structure, a thrombus (approx. $1.4 \times 0.6 \mathrm{~cm}$ ) in the left atrial appendage was detected 5 days after the cardiac intervention (Fig. 1b). Calibrated drug activity as a surrogate for the plasma concentration of apixaban was proven to be insufficient despite supervised oral intake during the hospital stay: the estimated trough plasma concentration $12 \mathrm{~h}$ after last intake was $18 \mathrm{ng} / \mathrm{mL}$ (expected range: $34-230 \mathrm{ng} / \mathrm{mL}$ ) and the estimated peak plasma concentration $3 \mathrm{~h}$ after last intake was $36 \mathrm{ng} / \mathrm{mL}$ (expected range: 69-321 ng/mL) [23, 24]. Thus, apixaban was replaced by $2 \times 150 \mathrm{mg}$ of dabigatran. However, this also resulted in low drug activity of the substance: the estimated trough plasma concentration $12 \mathrm{~h}$ after last intake was $26 \mathrm{ng} / \mathrm{mL}$ (expected range: $31-225 \mathrm{ng} / \mathrm{mL}$ ) and the estimated peak plasma concentration $3 \mathrm{~h}$ after last intake was $56 \mathrm{ng} / \mathrm{mL}$ (expected range: $64-443 \mathrm{ng} / \mathrm{mL}$ ) [24, 25]. External validation by a different laboratory showed no significant difference in results $(<1 \mathrm{ng} / \mathrm{mL})$. Furthermore, concomitant medication (ramipril, metoprolol retard, pantoprazole, atorvastatin, ipratropium bromide/fenoterol, and fluticasone/formoterol fumarate) had no interaction potential. Finally, phenprocoumon (INR target: 2.0-3.0) was chosen for continuation of oral anticoagulation. Five days after first intake of phenprocoumon, the patient's INR reached 2.1 and concomitant administration of dabigatran was terminated. The INR target of 2-3 was maintained thereafter. The patient was discharged with only minor neurological deficits (mild left-sided facial palsy).

Three months later, he had recovered completely from the stroke (no neurological deficits). A follow-up TEE showed no thrombus, and subsequent electrical cardioversion was performed.

\section{Discussion}

Catheter ablation and cardioversion in patients with symptomatic atrial fibrillation are widely performed to improve quality of life by restoring the sinus rhythm and thereby preventing left ventricular dysfunction and heart failure [2,3]. However, it remains controversial whether there is a prominent effect on reduction of stroke risk due to peri- and postprocedural thromboembolic complications [26, 27].

During cardioversion, errant atrial conduction is converted to ordered conduction by application of an electric current (electrical cardioversion) or antiarrhythmic medication

\section{Karger'=}




\section{Case Reports in Neurology}

Case Rep Neurol 2021;13:225-232

DOI: 10.1159/000515154

(c) 2021 The Author(s). Published by S. Karger AG, Basel www.karger.com/crn

Chae et al.: Stroke after Catheter Ablation despite Novel Oral Anticoagulant

(pharmacological/chemical cardioversion) [28, 29]. Although the risk of thromboembolic events is low in patients with atrial fibrillation under adequate chronic anticoagulation, ranging between 0.13 and $0.2 \%$, cardioversion leads to a temporary 3- to 4-fold increase in risk of stroke [30]. An explanation for this observation is that the procedure leads to atrial stunning, resulting in reduced flow velocity and thereby favoring thrombus formation [31, 32]. Moreover, a considerable rate of atrial fibrillation recurrence after ablation requires continuation of anticoagulation [33,34]. Consequently, pharmacological prevention of thromboembolic events despite cardiac intervention is crucial in patients with atrial fibrillation. For this purpose, NOACs are often preferred due to their improved safety profiles and noninferiority to vitamin $\mathrm{K}$ antagonists [35, 36]. A major advantage is a fixed dosing without requirement of frequent monitoring, owing to the predictable pharmacokinetic properties of NOACs [37]. Nevertheless, due to short half-lives of NOACs, noncompliance leads to insufficient drug activity and consequently to an increased risk of thromboembolic complications. Although NOACs are considered to have fewer drug-drug interactions than vitamin $\mathrm{K}$ antagonists, it has also been shown that the drug activity of NOACs is dependent on factors such as age, body weight, renal function, and even ethnic background [25, 38, 39].

In our case, the body weight was a probable explanation for the insufficient drug activity of the NOACs. The patient's BMI of $30.4 \mathrm{~kg} / \mathrm{m}^{2}$ met the WHO definition of obesity (obesity is a BMI $\geq 30$ ) [40]. The volume of distribution and drug clearance can be influenced by weight, resulting in either underdosing or overdosing of the substance, with a correspondingly enhanced risk of thromboembolism or bleeding, when fixed dosing is used. Although studies have not revealed clinically significant effects of obesity on the pharmacokinetic properties of NOACs [20,24], a correlation between nondiabetic obesity and increased glomerular filtration could be observed [41]. Furthermore, due to the altered liver weight, enzyme content, and metabolic rate along with the body size, variability in hepatic clearance is known to be correlated with obesity [42]. Hence, regarding apixaban, where renal excretion accounts for $27 \%$ of total apixaban clearance, an increased nonrenal elimination in our obese patient could be discussed [42]. In addition, a subanalysis of RE-LY data in regard to patients' characteristics revealed that due to reduced drug exposure, decreased peak concentrations, and shorter halflives, patients with obesity showed $21 \%$ lower estimated dabigatran plasma concentrations than patients with normal weight $[25,43,44]$. Another single-center, retrospective cohort study described a higher thromboembolic event rate among obese patients on dabigatran than among those on apixaban or rivaroxaban, suggesting an avoidance of dabigatran in obese patients until further studies would be conducted $[45,46]$.

In the clinical setting, there are situations where drug activity tests could facilitate improved decision-making - i.e., in assessment of the bleeding risk of invasive procedures or medical interventions, such as thrombolytic therapy for acute ischemic stroke - or determining drug concentrations for patients suffering from thromboembolic events despite oral anticoagulation $[47,48]$. Whereas vitamin $\mathrm{K}$ antagonists allow activity control by INR measurements, laboratory assessments of NOACs have appeared more challenging in the past few years. To date, diluted thrombin time and ecarin clotting time have been established for laboratory monitoring of dabigatran, as well as anti-factor Xa chromogenic assays for apixaban, edoxaban, and rivaroxaban [49]. However, these laboratory assays are accompanied by high costs and available only in select clinics.

Given the importance of oral anticoagulation for prevention of thromboembolic events, more studies regarding insufficient drug activity are required to validate the necessity of more

\section{Karger'=}




\section{Case Reports in Neurology}

Case Rep Neurol 2021;13:225-232

DOI: $10.1159 / 000515154$

(c) 2021 The Author(s). Published by S. Karger AG, Basel www.karger.com/crn

Chae et al.: Stroke after Catheter Ablation despite Novel Oral Anticoagulant

frequent drug activity controls for NOACs in patients with atrial fibrillation in high-risk situations.

\section{Statement of Ethics}

The paper does not include any research or study and is thus exempt from ethics committee approval. Written informed consent was obtained from the patient for publication of this case report and any accompanying images.

\section{Conflict of Interest Statement}

The authors have no conflicts of interest to declare.

\section{Funding Sources}

The authors did not receive any funding.

\section{Author Contributions}

W.H.C., B.F., and M.K. conceptualized and drafted the manuscript. H.W., I.D., and C.D. revised the manuscript. All authors read and approved the manuscript.

\section{References}

1 January CT, Wann LS, Calkins H, Chen LY, Cigarroa JE, Cleveland JC Jr, et al. 2019 AHA/ACC/HRS Focused Update of the 2014 AHA/ACC/HRS Guideline for the Management of Patients with Atrial Fibrillation: A Report of the American College of Cardiology/American Heart Association Task Force on Clinical Practice Guidelines and the Heart Rhythm Society in Collaboration with the Society of Thoracic Surgeons. Circulation. 2019 Jul;140(2):e125-51.

2 Mark DB, Anstrom KJ, Sheng S, Piccini JP, Baloch KN, Monahan KH, et al.; CABANA Investigators. Effect of Catheter Ablation vs Medical Therapy on Quality of Life among Patients with Atrial Fibrillation: The CABANA Randomized Clinical Trial. JAMA. 2019 Apr;321(13):1275-85.

3 Sandhu RK, Smigorowsky M, Lockwood E, Savu A, Kaul P, McAlister FA. Impact of Electrical Cardioversion on Quality of Life for the Treatment of Atrial Fibrillation. Can J Cardiol. 2017 Apr;33(4):450-5.

4 Marrouche NF, Brachmann J, Andresen D, Siebels J, Boersma L, Jordaens L, et al.; CASTLE-AF Investigators. Catheter Ablation for Atrial Fibrillation with Heart Failure. N Engl J Med. 2018 Feb;378(5):417-27.

5 Saliba W, Schliamser JE, Lavi I, Barnett-Griness O, Gronich N, Rennert G. Catheter ablation of atrial fibrillation is associated with reduced risk of stroke and mortality: a propensity score-matched analysis. Heart Rhythm. 2017 May;14(5):635-42.

6 Bunch TJ, Crandall BG, Weiss JP, May HT, Bair TL, Osborn JS, et al. Patients treated with catheter ablation for atrial fibrillation have long-term rates of death, stroke, and dementia similar to patients without atrial fibrillation. J Cardiovasc Electrophysiol. 2011 Aug;22(8):839-45.

7 Friberg L, Tabrizi F, Englund A. Catheter ablation for atrial fibrillation is associated with lower incidence of stroke and death: data from Swedish health registries. Eur Heart J. 2016 Aug;37(31):2478-87.

8 Packer DL, Mark DB, Robb RA, Monahan KH, Bahnson TD, Poole JE, et al.; CABANA Investigators. Effect of Catheter Ablation vs Antiarrhythmic Drug Therapy on Mortality, Stroke, Bleeding, and Cardiac Arrest among Patients with Atrial Fibrillation: The CABANA Randomized Clinical Trial. JAMA. 2019 Apr;321(13):1261-74.

\section{Karger'=}




\section{Case Reports in Neurology}

Case Rep Neurol 2021;13:225-232

DOI: 10.1159/000515154

(c) 2021 The Author(s). Published by S. Karger AG, Basel www.karger.com/crn

Chae et al.: Stroke after Catheter Ablation despite Novel Oral Anticoagulant

9 Ghanbari H, Başer K, Jongnarangsin K, Chugh A, Nallamothu BK, Gillespie BW, et al. Mortality and cerebrovascular events after radiofrequency catheter ablation of atrial fibrillation. Heart Rhythm. 2014 Sep;11(9):1503-11.

10 Barra S, Baran J, Narayanan K, Boveda S, Fynn S, Heck P, et al. Association of catheter ablation for atrial fibrillation with mortality and stroke: a systematic review and meta-analysis. Int J Cardiol. 2018 Sep;266:136-42.

11 Calkins H, Hindricks G, Cappato R, Kim YH, Saad EB, Aguinaga L, et al.; Document Reviewers. 2017 HRS/EHRA/ECAS/APHRS/SOLAECE expert consensus statement on catheter and surgical ablation of atrial fibrillation. Europace. 2018 Jan;20(1):e1-160.

12 Camm AJ, Kirchhof P, Lip GY, Schotten U, Savelieva I, Ernst S, et al.; European Heart Rhythm Association; European Association for Cardio-Thoracic Surgery. Guidelines for the management of atrial fibrillation: the Task Force for the Management of Atrial Fibrillation of the European Society of Cardiology (ESC). Eur Heart J. 2010 Oct;31(19):2369-429.

13 van Ryn J, Stangier J, Haertter S, Liesenfeld KH, Wienen W, Feuring M, et al. Dabigatran etexilate - a novel, reversible, oral direct thrombin inhibitor: interpretation of coagulation assays and reversal of anticoagulant activity. Thromb Haemost. 2010 Jun;103(6):1116-27.

14 Granger CB, Alexander JH, McMurray JJ, Lopes RD, Hylek EM, Hanna M, et al.; ARISTOTLE Committees and Investigators. Apixaban versus warfarin in patients with atrial fibrillation. N Engl J Med. 2011 Sep;365(11):981-92.

15 Patel MR, Mahaffey KW, Garg J, Pan G, Singer DE, Hacke W, et al.; ROCKET AF Investigators. Rivaroxaban versus warfarin in nonvalvular atrial fibrillation. N Engl J Med. 2011 Sep;365(10):883-91.

16 Camm AJ, Bounameaux H. Edoxaban: a new oral direct factor Xa inhibitor. Drugs. 2011 Aug;71(12):1503-26.

17 Byon W, Garonzik S, Boyd RA, Frost CE. Apixaban: A Clinical Pharmacokinetic and Pharmacodynamic Review. Clin Pharmacokinet. 2019 0ct;58(10):1265-79.

18 Ikeda K, Tachibana H. Clinical implication of monitoring rivaroxaban and apixaban by using anti-factor Xa assay in patients with non-valvular atrial fibrillation. J Arrhythm. 2016 Feb;32(1):42-50.

19 Breuer L, Ringwald J, Schwab S, Köhrmann M. Ischemic stroke in an obese patient receiving dabigatran. N Engl J Med. 2013 Jun;368(25):2440-2.

20 McCaughan GJ, Favaloro EJ, Pasalic L, Curnow J. Anticoagulation at the extremes of body weight: choices and dosing. Expert Rev Hematol. 2018 Oct;11(10):817-28.

21 Foerster KI, Hermann S, Mikus G, Haefeli WE. Drug-Drug Interactions with Direct Oral Anticoagulants. Clin Pharmacokinet. 2020 Aug;59(8):967-80.

22 Maus V, Behme D, Kabbasch C, Borggrefe J, Tsogkas I, Nikoubashman O, et al. Maximizing First-Pass Complete Reperfusion with SAVE. Clin Neuroradiol. 2018 Sep;28(3):327-38.

23 Dale BJ, Chan NC, Eikelboom JW. Laboratory measurement of the direct oral anticoagulants. Br J Haematol. 2016 Feb;172(3):315-36.

24 Steffel J, Verhamme P, Potpara TS, Albaladejo P, Antz M, Desteghe L, et al.; ESC Scientific Document Group. The 2018 European Heart Rhythm Association Practical Guide on the use of non-vitamin K antagonist oral anticoagulants in patients with atrial fibrillation: executive summary. Europace. 2018 Aug;20(8):1231-42.

25 Reilly PA, Lehr T, Haertter S, Connolly SJ, Yusuf S, Eikelboom JW, et al.; RE-LY Investigators. The effect of dabigatran plasma concentrations and patient characteristics on the frequency of ischemic stroke and major bleeding in atrial fibrillation patients: the RE-LY Trial (Randomized Evaluation of Long-Term Anticoagulation Therapy). J Am Coll Cardiol. 2014 Feb;63(4):321-8.

26 Airaksinen KE, Grönberg T, Nuotio I, Nikkinen M, Ylitalo A, Biancari F, et al. Thromboembolic complications after cardioversion of acute atrial fibrillation: the FinCV (Finnish CardioVersion) study. J Am Coll Cardiol. 2013 Sep;62(13):1187-92.

27 Di Biase L, Burkhardt JD, Santangeli P, Mohanty P, Sanchez JE, Horton R, et al. Periprocedural stroke and bleeding complications in patients undergoing catheter ablation of atrial fibrillation with different anticoagulation management: results from the Role of Coumadin in Preventing Thromboembolism in Atrial Fibrillation (AF) Patients Undergoing Catheter Ablation (COMPARE) randomized trial. Circulation. 2014 Jun;129(25):2638-44.

28 Andrade JG, Mitchell LB. Periprocedural Anticoagulation for Cardioversion of Acute Onset Atrial Fibrillation and Flutter: Evidence Base for Current Guidelines. Can J Cardiol. 2019 Oct;35(10):1301-10.

29 Femia G, Fetahovic T, Shetty P, Lee A. Novel Oral Anticoagulants in Direct Current Cardioversion for Atrial Fibrillation. Heart Lung Circ. 2018 Jul;27(7):798-803.

30 Klein HH. Electrical cardioversion for non-valvular atrial fibrillation - underestimated risk for thromboembolic complications? [in German]. Dtsch Med Wochenschr. 2013 Jun;138(24):1309-11.

31 Adeniran I, MacIver DH, Garratt CJ, Ye J, Hancox JC, Zhang H. Effects of Persistent Atrial Fibrillation-Induced Electrical Remodeling on Atrial Electro-Mechanics - Insights from a 3D Model of the Human Atria. PLoS One. 2015 Nov;10(11):e0142397.

32 Khan IA. Atrial stunning: basics and clinical considerations. Int J Cardiol. 2003 Dec;92(2-3):113-28.

\section{Karger'=}




\section{Case Reports in Neurology}

\begin{tabular}{l|l}
\hline Case Rep Neurol 2021;13:225-232 \\
\hline DOI: 10.1159/000515154 & $\begin{array}{l}\text { @ 2021 The Author(s). Published by S. Karger AG, Basel } \\
\text { www.karger.com/crn }\end{array}$ \\
\hline
\end{tabular}

Chae et al.: Stroke after Catheter Ablation despite Novel Oral Anticoagulant

33 Tieleman RG, Van Gelder IC, Crijns HJ, De Kam PJ, Van Den Berg MP, Haaksma J, et al. Early recurrences of atrial fibrillation after electrical cardioversion: a result of fibrillation-induced electrical remodeling of the atria? J Am Coll Cardiol. 1998 Jan;31(1):167-73.

34 Van Gelder IC, Crijns HJ, Van Gilst WH, Verwer R, Lie KI. Prediction of uneventful cardioversion and maintenance of sinus rhythm from direct-current electrical cardioversion of chronic atrial fibrillation and flutter. Am J Cardiol. 1991 Jul;68(1):41-6.

35 Goette A, Merino JL, Ezekowitz MD, Zamoryakhin D, Melino M, Jin J, et al.; ENSURE-AF investigators. Edoxaban versus enoxaparin-warfarin in patients undergoing cardioversion of atrial fibrillation (ENSUREAF): a randomised, open-label, phase 3b trial. Lancet. 2016 Oct;388(10055):1995-2003.

36 Brunetti ND, Tarantino N, De Gennaro L, Correale M, Santoro F, Di Biase M. Direct oral anti-coagulants compared to vitamin-K antagonists in cardioversion of atrial fibrillation: an updated meta-analysis. J Thromb Thrombolysis. 2018 May;45(4):550-6.

37 Chaudhary R, Sharma T, Garg J, Sukhi A, Bliden K, Tantry U, et al. Direct oral anticoagulants: a review on the current role and scope of reversal agents. J Thromb Thrombolysis. 2020 Feb;49(2):271-86.

38 Gibson CM, Yuet WC. Racial and Ethnic Differences in Response to Anticoagulation: A Review of the Literature. J Pharm Pract. 2019 [Online ahead of print].

39 Liesenfeld KH, Lehr T, Dansirikul C, Reilly PA, Connolly SJ, Ezekowitz MD, et al. Population pharmacokinetic analysis of the oral thrombin inhibitor dabigatran etexilate in patients with non-valvular atrial fibrillation from the RE-LY trial. J Thromb Haemost. 2011 Nov;9(11):2168-75.

40 Arroyo-Johnson C, Mincey KD. Obesity Epidemiology Worldwide. Gastroenterol Clin North Am. 2016 Dec;45(4):571-9.

41 Safouris A, Demulder A, Triantafyllou N, Tsivgoulis G. Rivaroxaban presents a better pharmacokinetic profile than dabigatran in an obese non-diabetic stroke patient. J Neurol Sci. 2014 Nov;346(1-2):366-7.

42 Upreti VV, Wang J, Barrett YC, Byon W, Boyd RA, Pursley J, et al. Effect of extremes of body weight on the pharmacokinetics, pharmacodynamics, safety and tolerability of apixaban in healthy subjects. Br J Clin Pharmacol. 2013 Dec;76(6):908-16.

43 Coons JC, Albert L, Bejjani A, Iasella CJ. Effectiveness and Safety of Direct Oral Anticoagulants versus Warfarin in Obese Patients with Acute Venous Thromboembolism. Pharmacotherapy. 2020 Mar;40(3):20410.

44 Martin K, Beyer-Westendorf J, Davidson BL, Huisman MV, Sandset PM, Moll S. Use of the direct oral anticoagulants in obese patients: guidance from the SSC of the ISTH. J Thromb Haemost. 2016 Jun;14(6):1308-13.

45 Kido K, Ngorsuraches S. Comparing the Efficacy and Safety of Direct Oral Anticoagulants with Warfarin in the Morbidly Obese Population with Atrial Fibrillation. Ann Pharmacother. 2019 Feb;53(2):165-70.

46 Kido K, Lee JC, Hellwig T, Gulseth MP. Use of Direct Oral Anticoagulants in Morbidly Obese Patients. Pharmacotherapy. 2020 Jan;40(1):72-83.

47 Eby C. Novel anticoagulants and laboratory testing. Int J Lab Hematol. 2013 Jun;35(3):262-8.

48 Cuker A, Siegal DM, Crowther MA, Garcia DA. Laboratory measurement of the anticoagulant activity of the non-vitamin K oral anticoagulants. J Am Coll Cardiol. 2014 Sep;64(11):1128-39.

49 Tripodi A. The laboratory and the direct oral anticoagulants. Blood. 2013 May;121(20):4032-5. 


\section{Case Reports in Neurology}
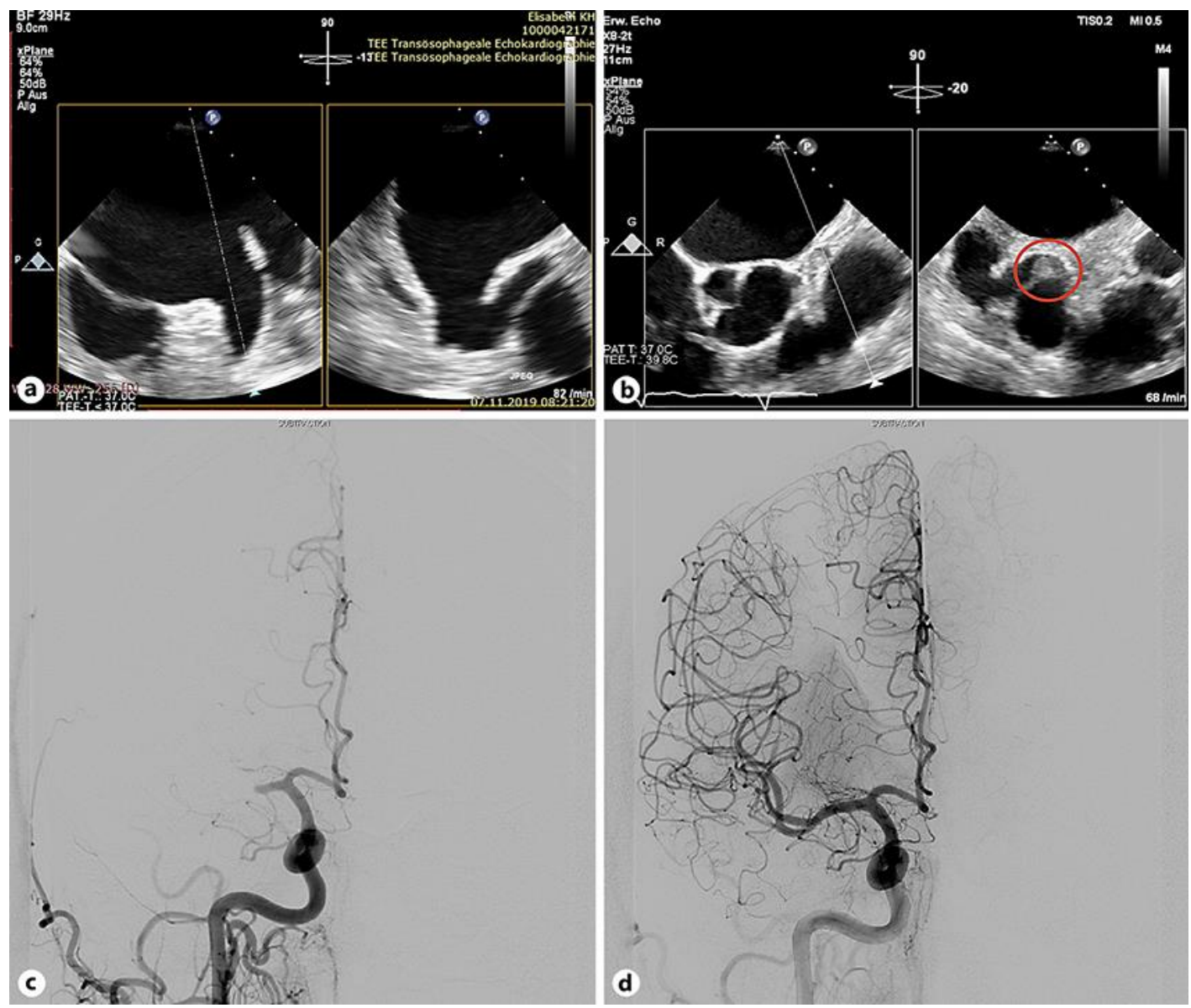

Fig. 1. Ultrasound and angiography images. a Images from transesophageal echocardiography directly prior to cardiac intervention depicting no pathological structure. $\mathbf{b}$ Images from transesophageal echocardiography 5 days after stroke showing a thrombus (approx. $1.4 \times 0.6 \mathrm{~cm}$ ) in the left atrial appendage. c, d Angiography images before (c) and after (d) mechanical thrombectomy of proximal M1 occlusion with one stent-retriever assisted vacuum-locked extraction (SAVE) resulted in successful reperfusion (TICI grade $2 b)$. 